filling a long.felt want of information regarding agricultural genetics in Italy. Vol. 1, No. 1 contains papers on such subjects as genetics of castor oil plant, genetics of lethargy of seed in and on colour of wheat, Jarovization of the potato and resistance to rust in wheat. The papers are written in Italian, but there is a summary in both Latin and English. An appendix contains abstracts of papers on genetical or plantbreeding subjects. The form and presentation of the journal are to be commended, but it might be thought desirable to obtain the aid of an English reviser for the English summaries; the summaries in the first issup do not represent adequately the Italian papers. 36

\section{Naval Mining and Degaussing}

A CATALOGjpahas ben issued of the exhibition now being Dold the Science Museurn, South Kensingt , o Arpesentative British and German nayal ming ofd degaussing material used during thp peond Wbld. War. During 1914-18, mines, aln ost without exception, had to be struck by the target in order to produce an explosion; but in the inter-war period detecting methods were developed which gave the mines greatly increased range of detection. These advances led to the 'ground' mine, laid on the sea-bed, operated either magnetically, electro-chemically or acoustically, or by the small changes of pressure which occur on the sea-bed, on the approach of the target vessel. The antidote to the magnetic mine used extensively by the Germans for the first time in November 1939 , was to reduce to a minimum the natural magnetism of ships by a process of 'degaussing'. The exhibition affords a comprehensive insight into the various methods and varied equipment employed, and also contains charts of the British naval mining achievement and of enemy shipping casualties due to British mines in the European war theatre, 1939-45.

\section{Institution of Naval Architects : Awards}

THE Coungl of the Institution of Naval Architects has made the following awards : Sir William White Post-gradaate Scholarship in Naval Architecture ( $\$ 150$ a year for two years) to Mr. Thomas Corin, of the Ship Division, National Physical Laboratory; Aluyhinium Development Association Research Scholarship in the application of light alloys to ship construction ( $\$ 400$ a year for two years) to Mr. E. C. B. Corlett; Elgar Scholarship in Naval Architecture (£175 a year) to Mr. R. L. Townsin, of H.M. Dockyard, Portsmouth, who will proceed to King's College, Newcastle-on-Tyne, for three years ; Parsons Scholarship in Marine Engineering ( $£ 170$ a year) to Mr. W. G. Wade, of H.M. Dockyard, Sheerness, who will proceed to Kipg's College, Newcastle-on-Tyne, for three years. Meted ' Observations in India in 1943-44 at Begumpet, Deccan, Indie

MoHD. A R. TAN has issued a pamphlet with this title whis gives details of meteor observations between lftinuary 1, 1943, and December 31, 1944, dufng a total watch of nearly 132 hours. The olstuvtions included the usual well-known shower metieors and in addition a number of exceptionally bright meteors, one of which, in May 1944, was of magnitude -4 . It is interesting to know that the total number observed in each year was nearly the same-1,044 in 1943 and 1,005 in 1944. Details of the paths of all the meteors were sent to Prof. C. P. Olivier, Flower Observatory, who arranged to have the paths plotted and radiants deduced, and a number of new radiants were found as a result. An interesting phenomenon was observed on October 2, 1943 , between $21 \mathrm{~h}$. and $22 \mathrm{~h}$. U.T. The sky appeared to be lit up with a peculiar glow, akin to non-polar aurora. No artificial lights were reported in the neighbourhood at the time, and no explanation has been given of the phenomenon.

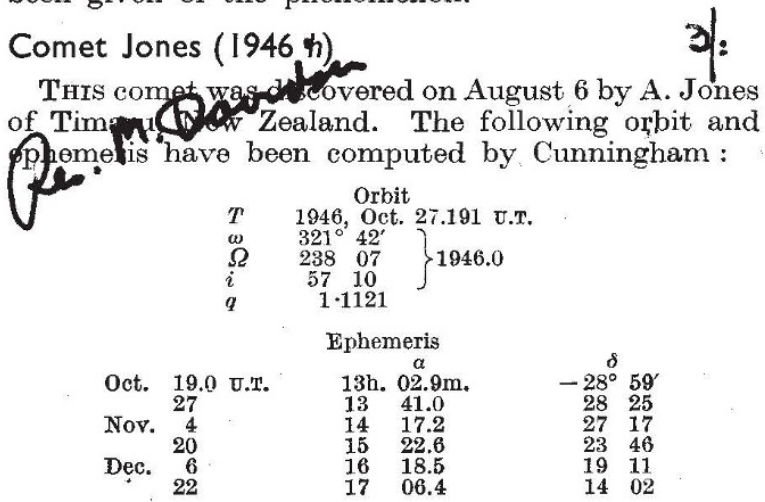

Its geocentric distances on the first and last dates are 2 and $2 \cdot 35$, and the heliocentric distances on the corresponding dates are $1 \cdot 12$ and $1 \cdot 42$. Its magnitude on the same dates will be about 7 and 9 .

\section{Announcements}

A MeETING has been arranged by a committee representatjye of the Society of Authors, Playwrights and Confosers, the International P.E.N. Club (Englis/Centre), the National Book League, and the Britim Association for the Advancement of Science, in/memory of H. G. Wells. Lord Beveridge will preside, and tributes will be paid by Prof. G. D. H. Cole, Sir Richard Gregory, Mr. David Low, Mr. Desmond MacCarthy and Mr. J. B. Priestley. The meeting, which is open to the public, will be held in the Royal Institution, Albemarle Street, London, W.1, on October 30 , at 3.0 p.m. Applications for tickets should be addressed to the Secretary, Wells Tribute Meeting, c/o The British Association, Burlington House, London, W.1.

Dr. Patrick D. Ritchie, head of the Department of Chemistry and Biology at the Leeds College of Technology, has been appointed head of the Department of Chemistry at the Central Technical College, Bimingham, in succession to Dr. J. A. Newton Friend. Dr. Ritchie is a graduate of the University of St. Andrews, where he was a student of Prof. Alex. McKenzie. On leaving the University he went to the research staff of Imperial Chemical Industries, Ltd., and he has had teaching and research experience in the University of London. Later he became chief chemist to Messrs. A. Reyrolle and Co., Ltd.

Dr. Fred Grundy, medical officer of health for Lutgh, has been appointed chairman of the Executive Committee of the British Social Hygiene Council in succession to the late Dr. Otto May.

The Leon Gaster Memorial Premium is awarded annually by the Illuminating Engineering Society for the bost contribution submitted to and published by the Society during the session. No award was made in 1944. Two awards are being made now, one to Dr. J. N. Aldington for his paper "Bright Light Sources", and one to Mr. G. T. Winch for his paper "Photometry and Colorimetry of Fluorescent and other Electric Discharge Lamps". 